\title{
Evaluation of impact of industrial effluents on intertidal sediments of a creek
}

\author{
S. P. Volvoikar · G. N. Nayak
}

Received: 18 August 2011/Revised: 15 December 2011/Accepted: 4 April 2012/Published online: 23 April 2013

(C) Islamic Azad University (IAU) 2013

\begin{abstract}
A large amount of material in the form of industrial effluents and urban sewage containing metal contaminants directly enters Dudh creek. Metals on entering the creek tend to settle at the bottom and become part of the sediments. The distribution of metals with depth reflects changes in their supply as well as diagenetic modifications with time. In the present study, an attempt has been made to understand the impact of waste discharged from Tarapur Maharashtra Industrial Development Corporation on Dudh creek. Two cores were collected, one close to the creek mouth and the other in the inner part of the creek. Sediment component, organic carbon and metal (vanadium, copper, nickel, lead, zinc, manganese, iron and aluminium) analyses were carried out on the two cores. The variation in the distribution of sediment components with depth reflects changes in hydrodynamic condition of the creek over the years. Increase in concentration of most of the metals in the upper part of the cores indicates additional input in recent years. The core collected in the inner part of the creek showed higher metal and organic carbon concentration as compared to the downstream core. This was very well supported by distribution of points on an isocon plot. Enrichment factor and index of geoaccumulation were used to find the extent of pollution in sediments of the creek. Correlation and R-mode factor analysis
\end{abstract}

S. P. Volvoikar · G. N. Nayak ( $\square)$

Department of Marine Sciences,

Goa University, Goa 403206, India

e-mail: gnnayak@unigoa.ac.in have also been computed to understand the association and source of metal input in sediments of Dudh creek.

Keywords Anthropogenic - Hydrodynamic condition . Isocon plot · Metals · Pollution · Source

\section{Introduction}

Creeks are the intertidal regions developed along the coasts and are sites of major port, industrial, urban and recreational activities (Ridgway and Shimmield 2002). As a result, large amounts of contaminants both organic as well as inorganic are being added to the coastal environments (Valette-Silver 1993; Williams et al. 1994; Fianko et al. 2007; Ip et al. 2007). Creeks are low-energy environments and favor deposition of fine-grained sediments along with associated metals and organic matter. In recent years the creeks in western India have been under stress due to enhanced release of material from increasing industrialization and urbanization. In the intertidal region, flocculation occurs due to mixing of freshwater with saline waters, wherein metals from dissolved phase tend to get adsorbed onto suspended clay particles, form a complex with organic compounds or co-precipitate with oxides and hydroxides (Stecko and Bendell-Young, 2000; Liaghati et al. 2003). Due to increase in size of floccules and slackening of flow velocity, metals along with suspended particles settle at the bottom and become part of the sediments. Sondi et al. (1995) have stated that salt-induced flocculation of finegrained particles was found to be the dominant process that governs the sedimentation pattern of clayey sediments. Further, enrichment of sediments with metals and organic matter of terrestrial origin in the upper estuary is related to salt-induced coagulation of colloidal inorganic and organic 
materials (Sondi et al. 2008). Trace metal enrichment is of major concern because of their toxicity, persistence and the possibility of their entering the food chain.

Creeks are very sensitive to climatic and environmental changes that are recorded effectively in different geochemical phases of sediments. Distribution pattern of particles in sediment cores reflect prevailing hydrodynamic conditions of the past and measurements of metals in sediment cores provide records of historical contamination (Ramesh et al. 2002; Vaalgamma and Conley 2008; Hwang et al. 2009; Ruiz et al. 2009). Earlier studies have shown different levels of pollution or contamination in core samples of the intertidal regions of the east and west coast of India (Achyuthan et al. 2002; Ayyamperumal et al. 2006; Priju and Narayana, 2006; Janaki-Raman et al. 2007; Kwokal et al. 2008; Kumar and Edward 2009; Fernandes et al. 2011).

Kharekuran-Murbe (Dudh) macrotidal creek with a spring and neap tidal range of 5.35 and 2.1 (Swamy et al. 1982), respectively, is located in Thane District of Northern Maharashtra coast (Fig. 1). The freshwater to the creek is supplied by Dudh River. The creek is approximately $23 \mathrm{~km}$ long and shows a meandering path from the mouth to the upper limit of tidal influence. The catchment area is underlain by basaltic lava flows that erupted through fissures during the Late Cretaceous Period to the early Eocene Epoch and recent alluvium consisting of sands and clays overly the lava flows (Naik et al. 2007).

Tarapur Maharashtra Industrial Development Corporation (MIDC) with a number of industrial units lies in close proximity to the creek. The wastewater generated from the cities located in the region along with industrial effluent is finally disposed in the creeks (MPCB 2005).
The addition of industrial effluents along with municipal wastes has resulted in the deterioration of water quality of the creek (Naik et al. 2007).

In this study two sediment cores were collected, during field survey carried out from 20th to 29th May 2009, representing the mouth $\left(19^{\circ} 44^{\prime} 43.9^{\prime \prime} \mathrm{N}, 72^{\circ} 42^{\prime} 39.6^{\prime \prime} \mathrm{E}\right)$ and the inner part $\left(19^{\circ} 46^{\prime} 13.0^{\prime \prime} \mathrm{N}, 72^{\circ} 45^{\prime} 15^{\prime \prime} \mathrm{E}\right)$ of Dudh creek. The study was carried out with an objective to understand the variation in distribution of metals in sediments with time and the possible influence of Tarapur MIDC on the creek.

\section{Materials and methods}

The two sediment cores representing the mouth and inner part of the creek and having lengths of 56 and $30 \mathrm{~cm}$, respectively, were collected from the intertidal region of Dudh creek with the help of a handheld PVC corer. Sampling was carried out during low tide. The cores were subsampled at $2 \mathrm{~cm}$ intervals with the help of a plastic knife to avoid contamination. The sub-samples were then placed in labeled plastic bags, sealed and kept in the ice box. In the laboratory, the sub-samples were dried in an oven at $60{ }^{\circ} \mathrm{C}$. Part of the sample was homogenized with the help of agate mortar and pestle and was used for organic carbon and metal analysis. Sediment granulometric components (sand:silt:clay) were analyzed by wet sieving and pipette method following Folk (1968). The organic carbon was estimated using the method given by Gaudette et al. (1974). This method utilizes exothermic heating and oxidation of the sediment with $\mathrm{K}_{2} \mathrm{Cr}_{2} \mathrm{O}_{7}$ and concentrated $\mathrm{H}_{2} \mathrm{SO}_{4}$. Excess dichromate is titrated with $0.5 \mathrm{~N} \mathrm{Fe}\left(\mathrm{NH}_{4}\right)_{2-}$ $\mathrm{SO}_{4} 6 \mathrm{H}_{2} \mathrm{O}$ solution to a sharp one drop end point. For total
Fig. 1 Location of core samples collected from Kharekuran-Murbe (Dudh) creek, Maharashtra

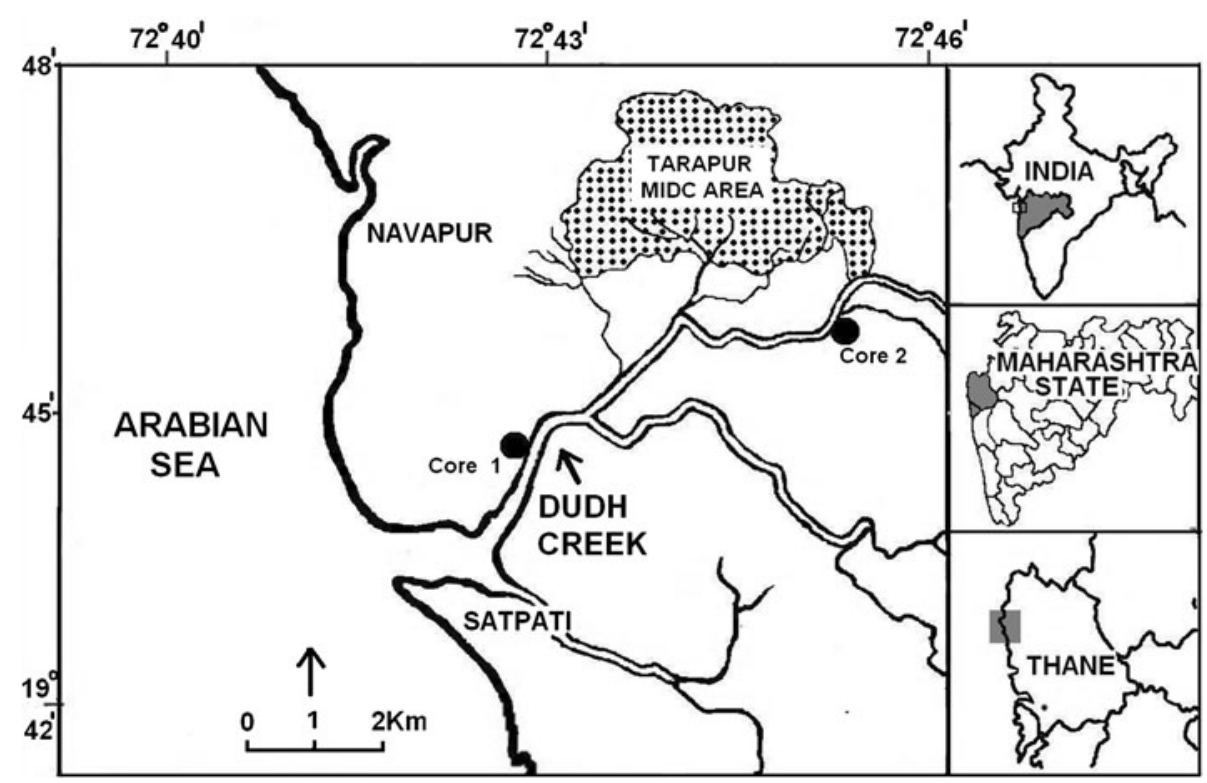


decomposition of sediments, $0.3 \mathrm{~g}$ of finely powdered sediment sample was digested in open Teflon beaker. $10 \mathrm{ml}$ of 7:3:1 acid mixture of $\mathrm{HF}, \mathrm{HNO}_{3}$ and $\mathrm{HClO}_{4}$ was added to sample, kept overnight and later dried on hot plate (at $70^{\circ} \mathrm{C}$ ). Again $5 \mathrm{ml}$ of the above acid mixture was added to the beaker and dried for $1 \mathrm{~h}$ in order to ensure complete digestion of the sediment. To this $2 \mathrm{ml}$ of concentrated $\mathrm{HCl}$ was added and dried completely. To the dried sample $10 \mathrm{ml}$ of $1: 1 \mathrm{HNO}_{3}$ was added and warmed for few minutes. The solution was then made to $100 \mathrm{ml}$ using Milli Q water and was then stored in pre-cleaned plastic bottle. The solutions obtained for all the sediment samples were then aspirated into the flame of atomic absorption spectrophotometer (Varian AA240FS) for the analyses of metals viz. vanadium (V), copper $(\mathrm{Cu})$, nickel $(\mathrm{Ni})$, lead $(\mathrm{Pb})$, zinc $(\mathrm{Zn})$, manganese $(\mathrm{Mn})$, iron $(\mathrm{Fe})$ and aluminium (Al). Care was taken to avoid contamination at every step for all the parameters studied. All the reagents used for this study were of analytical grade. Reagent blanks without sample and certified reference standard from the Canadian National Bureau of Standards (BCSS-1) were also treated following the above-mentioned procedure and analyzed along with the sample solutions. Reagent blanks indicated absence of contamination for all the metals studied. The accuracy of the analytical procedure was assessed using certified standard reference material (BCSS1). Accuracy was $\pm 5 \%$ for $\mathrm{Mn}$ and $\mathrm{V}, \pm 6 \%$ for $\mathrm{Fe}, \mathrm{Cu}$, $\mathrm{Ni}$ and $\mathrm{Al}, \pm 9 \%$ for $\mathrm{Zn}$ and $\mathrm{Pb}$. The atomic absorption spectrophotometer (AA240FS) was standardized by calibration curve method before analyzing the samples for metal concentration. The calibration standards of different concentrations were prepared for all the metals from the stock solutions $(1,000 \mathrm{mg} / \mathrm{l})$. Reproducibility of the instrument was checked by analyzing duplicate random samples. The precision obtained for the metals is as follows: Fe $2.19 \%$, Mn $3.04 \%$, Al $3.24 \%$, V $2.33 \%, \mathrm{Cu}$ $2.75 \%$, Ni $2.89 \%, \mathrm{~Pb} 2.26 \%$ and $\mathrm{Zn} 3.67 \%$ of the standard deviation (\%SD).

Statistical correlation and R-mode factor analyses were carried out on sediment components, organic carbon and metals of the two cores by using the software STATISTICA (StatSoft 1999). Enrichment factor (EF) and index of geoaccumulation $\left(I_{\mathrm{geo}}\right)$ were computed to understand the enrichment of metal concentrations and the degree of pollution in sediments of the creek.

Enrichment factor (EF) proposed by Simex and Helz (1981) was calculated using the average metal concentration of the earth's crust (Wedepohl 1995) according to the following equation (Dai et al. 2007).

Enrichment factor $=\left(\mathrm{C}_{\text {sample }} / \mathrm{Al}_{\text {sample }}\right) /\left(\mathrm{C}_{\text {crust }} / \mathrm{Al}_{\text {crust }}\right)$

where, $\mathrm{C}_{\text {sample }}$ and $\mathrm{C}_{\text {crust }}$ is the concentration of the element in the sample and in the continental crust, respectively.
Table 1 EF showing seven levels of contamination (Chen et al. 2007)

\begin{tabular}{ll}
\hline EF & Level of contamination \\
\hline$<1$ & No enrichment \\
$<3$ & Minor enrichment \\
$3-5$ & Moderate enrichment \\
$5-10$ & Moderately severe enrichment \\
$10-25$ & Severe enrichment \\
$25-50$ & Very severe enrichment \\
$>50$ & Extremely severe enrichment \\
\hline
\end{tabular}

Table $2 I_{\text {geo }}$ class showing sediment quality (Müller 1969)

\begin{tabular}{lll}
\hline$I_{\text {geo }}$ & $I_{\text {geo }}$ classes & Sediment quality \\
\hline$<0$ & 0 & Unpolluted \\
$0-<1$ & 1 & Unpolluted and moderately polluted \\
$1-2$ & 2 & Moderately polluted \\
$2-3$ & 3 & Moderately to highly polluted \\
$3-4$ & 4 & Highly polluted \\
$4-5$ & 5 & Highly to very highly polluted \\
$>5$ & 6 & Very highly polluted \\
\hline
\end{tabular}

$\mathrm{Al}_{\text {sample }}$ and $\mathrm{Al}_{\text {crust }}$ represent concentration of $\mathrm{Al}$ in the sample and in the continental crust, respectively. In this study, Al is used as a normalizer, because, trace element concentrations can be normalized to an element which is conservative with respect to chemical weathering and which has no significant anthropogenic source and $\mathrm{Al}$ fulfills this requirement (Wang et al. 2008). EF is divided into seven classes of contamination (Chen et al. 2007) as shown in Table 1. Geoaccumulation index as proposed by Müller (1969) was calculated as:

$\mathrm{I}_{\mathrm{geo}}=\log _{2} C_{n} / 1.5 B_{n}$

where, $C_{\mathrm{n}}$ is the concentration of the studied element and $B_{\mathrm{n}}$ is the geochemical background value taken from global average shale for element ' $n$ ' and factor 1.5 is used to compensate for lithogenic variations in background data. $I_{\text {geo }}$ is divided into seven classes and are shown in Table 2.

\section{Results and discussion}

Sediment components and organic carbon

In the core collected from the mouth of the creek (Core 1) the percentage of sand varies from 11.3 to $85.8 \%$ (avg. $32.6 \%$ ), that of silt varies from 6.64 to $38.6 \%$ (avg. $30.7 \%$ ) and of clay from 7.6 to $58 \%$ (avg. $36.7 \%$ ). The organic carbon value varies from 0.24 to $1.73 \%$ (avg. 


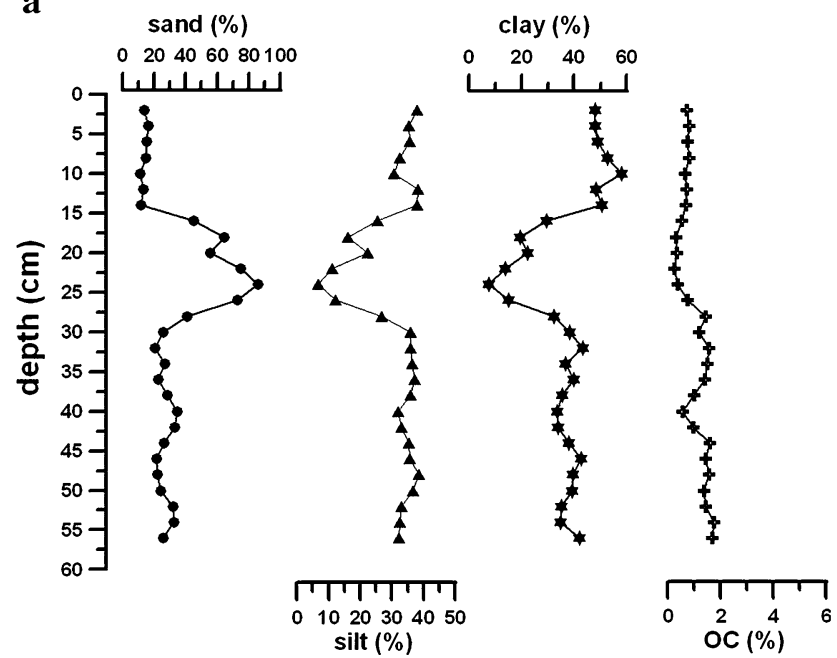

b

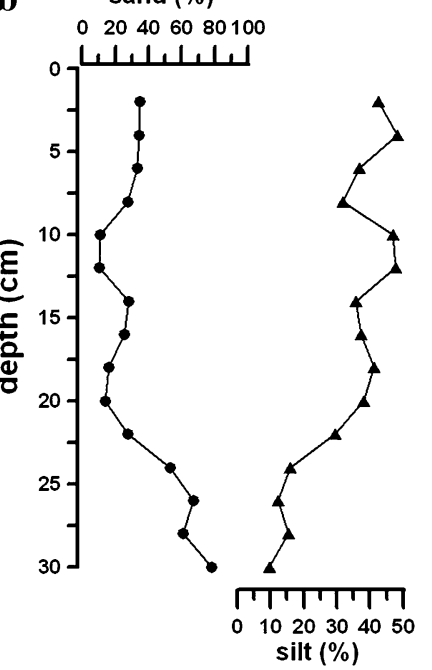

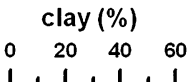
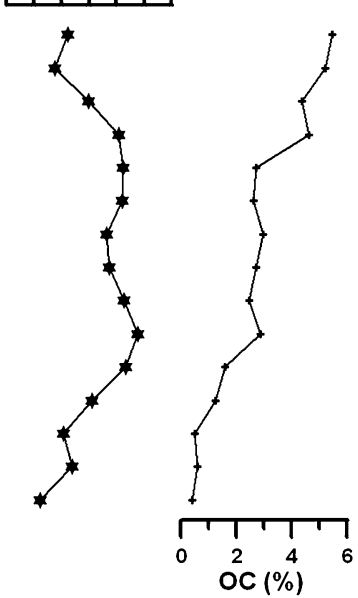

Fig. 2 Depth distribution of sediment components and organic carbon a core collected towards the mouth $\mathbf{b}$ core collected towards the inner portion of the creek

$0.99 \%)$. From the distribution pattern of sediment components (Fig. 2a), the core can be divided into three sections, the lower (56 to $30 \mathrm{~cm}$ ), middle (30 to $14 \mathrm{~cm}$ ) and the upper (14 cm to surface) sections. In the lower section of the core, fluctuating trend is observed with not much variation in sand percentage which is compensated by finer sediment fractions. In the middle section of the core, sand percentage increases drastically from 30 to $24 \mathrm{~cm}$. Further up, sand concentration decreases up to $14 \mathrm{~cm}$. The variation in sand percentage is compensated by silt and clay. In the upper section, sand percentage is relatively low and is almost constant. The clay percentage is high in this section, with a slight decrease at $12 \mathrm{~cm}$ depth, followed by an increase up to $10 \mathrm{~cm}$; where clay concentration is highest. Further up, a gradual decrease in clay up to the surface is seen which is compensated by silt. Organic carbon value is relatively higher in the lower section as compared to the middle and upper sections.

In the core collected from the inner part of the creek (Core 2) the abundance of sand varies from 10.3 to $78.0 \%$ (avg. $34.7 \%$ ), of silt from 9.74 to $48.3 \%$ (avg. $32.7 \%$ ) and of clay from 11.02 to $47.7 \%$ (avg. $32.7 \%$ ). The organic carbon varies from 0.38 to $5.45 \%$ (avg. $2.68 \%$ ). An overall decreasing trend of sand percentage is observed from the bottom up to $10 \mathrm{~cm}$ of the core, above $10 \mathrm{~cm}$ almost constant trend (Fig. 2b) is observed. Silt and organic carbon show an overall increasing trend. The clay is more in the middle of the core and decreases towards the bottom and top of the core. Further, from the distribution pattern of sediment components with depth, the core can be divided into two sections, viz. a lower section from bottom to $20 \mathrm{~cm}$ and the upper section from $20 \mathrm{~cm}$ to the surface. In the lower section, sand decreases and is compensated by silt and clay. Above this, in the upper section of the core, sand shows gradual increasing trend with slightly lower values between 12 and $10 \mathrm{~cm}$. Silt and clay largely compensate for the variation in sand percentage at all depths except near the surface of the core between $8 \mathrm{~cm}$ to surface wherein increase in silt percentage up to $4 \mathrm{~cm}$ depth followed by subsequent decrease at the surface is compensated by clay. Organic carbon shows an overall increasing trend with a peak at $8 \mathrm{~cm}$ depth.

In the core collected near the creek mouth, the high sand content in the middle section reflects a higher hydrodynamic energy as the grain size of sediment reflects prevailing hydrodynamic condition (Dolch and Hass 2008). Waves and tides associated with currents must have facilitated deposition of coarser sediment fraction carrying away finer sediment component (Siraswar and Nayak 2011). Further, abrupt change in sand percentage suggests a transition from a relatively high-energy depositional environment to lower-energy environment (Fox et al. 1999). Higher organic carbon values in the lower section are associated with higher values of finer sediments. Distribution of organic carbon matches with silt between 44 and $36 \mathrm{~cm}$. Also in the middle section of the core, variation in organic carbon matches the variation in silt and clay showing decrease up to $24 \mathrm{~cm}$ followed by an increase, thus reflecting the incorporation of organic matter to the finest fractions of sediments by adsorption phenomena (Keil et al. 1994). In the upper section, the organic carbon is almost constant with slightly increasing trend except near the surface where slight decrease is noted. Variation of organic carbon agrees very well with share of finer fractions between 28 and $8 \mathrm{~cm}$ indicating a close relationship. The higher values of organic carbon associated 


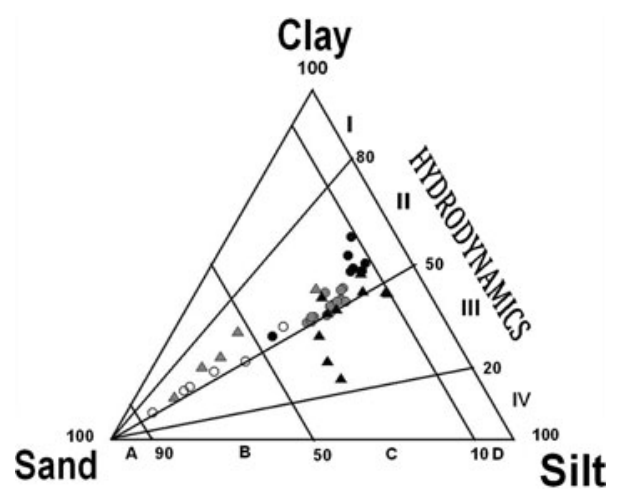

Fig. 3 Ternary diagram showing deposition of sand:silt:clay under varying hydrodynamic conditions after Pejrup (1988). Circles represent core collected towards the mouth and triangles, core collected from the inner portion of the creek. The black color represents the upper section, empty symbols represent middle and grey color is used to represent lower section of the cores

with finer sediment component, namely silt in the upper section of the core collected from inner portion of the creek indicates enhanced supply of organic material from the overlying water column in recent years (Badr et al. 2009) probably through polluted waters.

An attempt has been made to understand the hydrodynamic conditions in which sediments have been deposited over a period of time within the creek using ternary diagram proposed by Pejrup (1988). Diagram (Fig. 3) is divided into four sections (I-IV) reflecting increasingly violent hydrodynamic conditions. Each section is further divided into four classes (A-D) according to their sand content. Thus, the triangle has been divided into 16 groups each having a different number and a letter providing the groups with unique characteristics. The majority of sediment components of Dudh creek fall in group II (B and C) indicating deposition of sediments under quiet hydrodynamic conditions, except for the surface sediments of core collected from the inner portion of the creek which fall in group III (C) indicating deposition of sediments under relatively higher (violent) hydrodynamic conditions in recent years. Thus the ternary diagram helped in understanding a change from calm to relatively violent hydrodynamic conditions of Dudh creek with time. The spatial distribution of sediment components in the creek also revealed relatively higher average percentage of sand and silt and lower average percentage of clay in the core collected from the inner part of the creek as compared to the core collected from the mouth. Creek with just $23 \mathrm{~km}$ length and with Deccan basalts as the main geological formation in the catchment area, large variation in natural sediment input and mineralogy is not expected. However, around 2,000 mm rainfall received between June and September every year may bring mixed size sediment material and allow deposition of coarser sediments in the inner portion of the creek. The wide range of sediment components at two locations therefore indicate differences in hydrodynamics of depositional environments (He et al. 2006) and type of material retained at these locations.

The correlation between sediment components, organic carbon and metals in both cores are presented in Tables 3, 4. In core collected towards the mouth, silt shows significant positive correlation with clay and organic carbon, indicating association of organic matter by fine sediment fraction, while in core collected from the inner portion of the creek, silt shows significant relationship only with organic carbon.

\section{$\mathrm{Fe}, \mathrm{Mn}$ and $\mathrm{Al}$}

In the core collected towards the mouth Fe varies from 7.31 to $10.8 \%$ (avg $8.96 \%$ ) while $\mathrm{Mn}$ ranges from 1038 to $2144 \mathrm{ppm}$ (avg. $1546 \mathrm{ppm}$ ). The concentration of Fe and

Table 3 Correlation between sand, silt, clay, organic carbon and metals in core collected towards the mouth of the creek

\begin{tabular}{|c|c|c|c|c|c|c|c|c|c|c|c|c|}
\hline & Sand $(\%)$ & Silt (\%) & Clay (\%) & $\mathrm{OC}(\%)$ & $\mathrm{V}(\mathrm{ppm})$ & $\mathrm{Cu}(\mathrm{ppm})$ & Ni (ppm) & $\mathrm{Pb}(\mathrm{ppm})$ & $\mathrm{Zn}(\mathrm{ppm})$ & Mn (ppm) & $\mathrm{Fe}(\%)$ & $\mathrm{Al}(\%)$ \\
\hline Sand $(\%)$ & 1.00 & & & & & & & & & & & \\
\hline Silt (\%) & -0.95 & 1.00 & & & & & & & & & & \\
\hline Clay (\%) & -0.97 & 0.85 & 1.00 & & & & & & & & & \\
\hline $\mathrm{OC}(\%)$ & -0.46 & 0.57 & 0.34 & 1.00 & & & & & & & & \\
\hline $\mathrm{V}(\mathrm{ppm})$ & 0.43 & -0.52 & -0.34 & -0.51 & 1.00 & & & & & & & \\
\hline $\mathrm{Cu}(\mathrm{ppm})$ & 0.21 & -0.44 & -0.03 & -0.63 & 0.65 & 1.00 & & & & & & \\
\hline $\mathrm{Ni}(\mathrm{ppm})$ & -0.25 & -0.01 & 0.42 & -0.46 & 0.32 & 0.79 & 1.00 & & & & & \\
\hline $\mathrm{Pb}(\mathrm{ppm})$ & -0.21 & 0.14 & 0.24 & 0.08 & 0.21 & 0.31 & 0.25 & 1.00 & & & & \\
\hline $\mathrm{Zn}(\mathrm{ppm})$ & 0.17 & -0.27 & -0.09 & -0.47 & 0.28 & 0.59 & 0.28 & 0.03 & 1.00 & & & \\
\hline $\mathrm{Mn}(\mathrm{ppm})$ & 0.41 & -0.50 & -0.32 & -0.72 & 0.55 & 0.72 & 0.37 & 0.10 & 0.80 & 1.00 & & \\
\hline $\mathrm{Fe}(\%)$ & 0.25 & -0.45 & -0.08 & -0.77 & 0.58 & 0.89 & 0.68 & 0.25 & 0.65 & 0.77 & 1.00 & \\
\hline $\mathrm{Al}(\%)$ & -0.23 & 0.13 & 0.28 & 0.12 & 0.30 & 0.29 & 0.22 & 0.40 & 0.42 & 0.23 & 0.23 & 1.00 \\
\hline
\end{tabular}

* Values in bold are significant at $p<0.05, N=28$ (Casewise deletion of missing data) 
Table 4 Correlation between sand, silt, clay, organic carbon and metals in core collected from the inner part of the creek

\begin{tabular}{|c|c|c|c|c|c|c|c|c|c|c|c|c|}
\hline & Sand $(\%)$ & Silt (\%) & Clay (\%) & $\mathrm{OC}(\%)$ & $\mathrm{V}(\mathrm{ppm})$ & $\mathrm{Cu}(\mathrm{ppm})$ & $\mathrm{Ni}(\mathrm{ppm})$ & $\mathrm{Pb}(\mathrm{ppm})$ & $\mathrm{Zn}(\mathrm{ppm})$ & $\mathrm{Mn}(\mathrm{ppm})$ & $\mathrm{Fe}(\%)$ & $\mathrm{Al}(\%)$ \\
\hline Sand $(\%)$ & 1.00 & & & & & & & & & & & \\
\hline Silt (\%) & -0.89 & 1.00 & & & & & & & & & & \\
\hline Clay (\%) & -0.83 & 0.48 & 1.00 & & & & & & & & & \\
\hline $\mathrm{OC}(\%)$ & -0.54 & 0.76 & 0.11 & 1.00 & & & & & & & & \\
\hline $\mathrm{V}(\mathrm{ppm})$ & -0.44 & 0.64 & 0.06 & 0.82 & 1.00 & & & & & & & \\
\hline $\mathrm{Cu}(\mathrm{ppm})$ & -0.60 & 0.72 & 0.27 & 0.90 & 0.91 & 1.00 & & & & & & \\
\hline Ni(ppm) & -0.80 & 0.80 & 0.56 & 0.72 & 0.45 & 0.71 & 1.00 & & & & & \\
\hline $\mathrm{Pb}(\mathrm{ppm})$ & 0.67 & -0.69 & -0.43 & -0.63 & -0.63 & -0.69 & -0.64 & 1.00 & & & & \\
\hline $\mathrm{Zn}(\mathrm{ppm})$ & -0.38 & 0.63 & -0.04 & 0.94 & 0.82 & 0.86 & 0.55 & -0.65 & 1.00 & & & \\
\hline $\mathrm{Mn}(\mathrm{ppm})$ & 0.33 & -0.51 & -0.02 & -0.86 & -0.59 & -0.63 & -0.52 & 0.39 & -0.77 & 1.00 & & \\
\hline $\mathrm{Fe}(\%)$ & 0.26 & -0.01 & -0.49 & 0.19 & -0.06 & -0.07 & 0.05 & 0.24 & 0.12 & -0.28 & 1.00 & \\
\hline $\mathrm{Al}(\%)$ & -0.64 & 0.35 & 0.79 & -0.01 & 0.20 & 0.26 & 0.39 & -0.41 & -0.14 & 0.19 & -0.40 & 1.00 \\
\hline
\end{tabular}

* Values in bold are significant at $p<0.05, N=15$ (Casewise deletion of missing data)
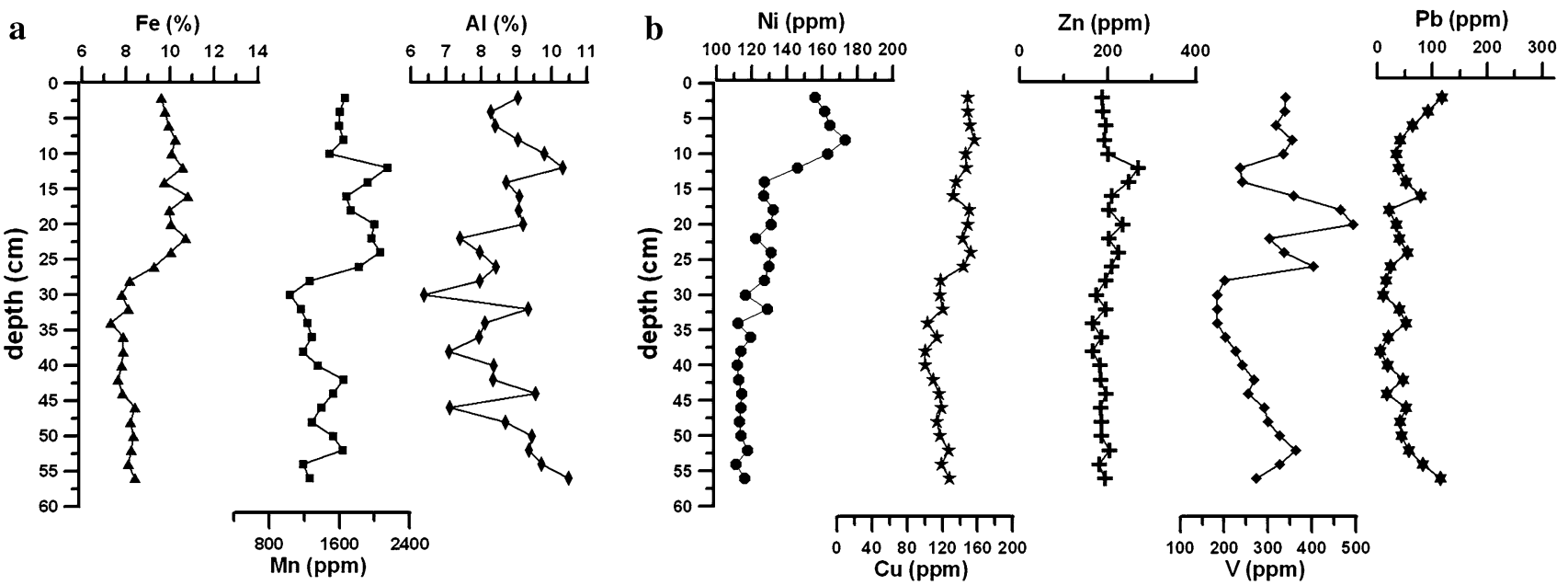

Fig. 4 Depth distribution of metals a $\mathrm{Fe}, \mathrm{Mn}$ and $\mathrm{Al} \mathrm{b} \mathrm{Ni,} \mathrm{Cu,} \mathrm{Zn}, \mathrm{V}$ and $\mathrm{Pb}$ in core collected towards the mouth

$\mathrm{Mn}$ is low in the lower section of the core as compared to middle and upper sections (Fig. 4a). In the lower section Fe is observed to show an overall decreasing trend. Mn also decreases in this section with fluctuating trend. In the middle section, a sudden and large increase in $\mathrm{Fe}$ concentration up to $22 \mathrm{~cm}$ is observed. Above this Fe concentration decreases up to $14 \mathrm{~cm}$. The Fe concentration is high in this section. Mn concentration varies the same way as $\mathrm{Fe}$ in this section and shows a sudden increase up to the depth of $24 \mathrm{~cm}$ which further decreases. In the upper section of the core, Fe shows a gradual decrease towards the surface, while Mn shows similar distribution pattern as that of Fe up to the depth of $10 \mathrm{~cm}$ with the highest value at $12 \mathrm{~cm}$, above which Mn concentration is almost constant.

In the core collected from the inner portion of the creek, Fe varies from 8.55 to $13.1 \%$ (avg. $10.2 \%$ ) and Mn ranges from 748 to $2,347 \mathrm{ppm}$ (avg. $1616 \mathrm{ppm}$ ). In the lower section of the core (Fig. 5a) Fe shows slightly increasing trend with the same point-to-point variation as that of clay and silt from bottom to $22 \mathrm{~cm}$, while Mn decreases in this section and has an opposite trend to that of Fe. A similar decrease has also been noted for sand in this section, thus, indicating the difference in association of the two metals with sediment components. Further in the upper section, Fe shows a decreasing trend up to the depth of $16 \mathrm{~cm}$ followed by a fluctuating trend up to $6 \mathrm{~cm}$ and then increase towards the surface with the highest value at $4 \mathrm{~cm}$ depth. The sudden increase in $\mathrm{Fe}$ concentration may be due to the recent addition of wastes from industries present in the catchment area making their way directly or indirectly to the creek (Bhagure and Mirgane 2010). The Mn shows an increasing trend from 20 to $12 \mathrm{~cm}$ depth, with the highest concentration at $12 \mathrm{~cm}$ depth. Above this $\mathrm{Mn}$ decreases drastically up to $8 \mathrm{~cm}$ followed by a gradual decrease up to 

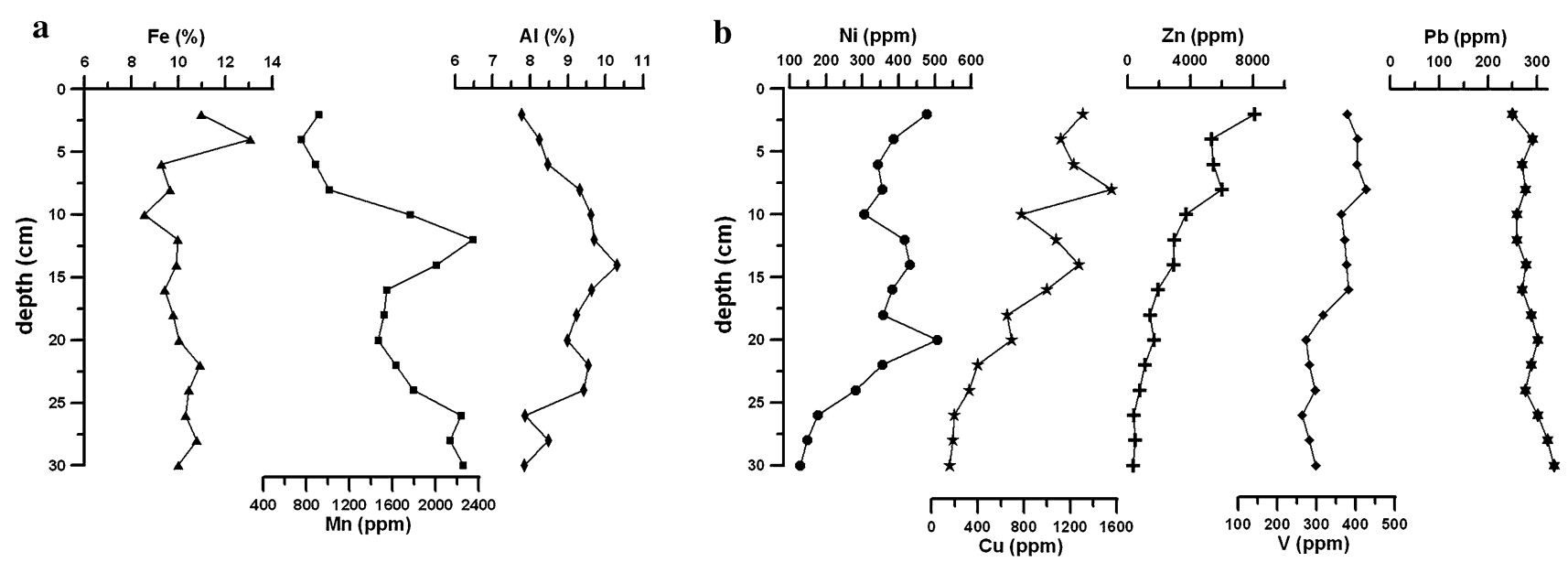

Fig. 5 Depth distribution of metals a Fe, $\mathrm{Mn}$ and $\mathrm{Al} \mathrm{b} \mathrm{Ni}, \mathrm{Cu}, \mathrm{Zn}, \mathrm{V}$ and $\mathrm{Pb}$ in core collected from the inner portion of the creek

$4 \mathrm{~cm}$. Mn variation matches clay in the upper section between $14 \mathrm{~cm}$ up to the surface of the core, while $\mathrm{Fe}$ concentration shows a slight similarity to silt.

Low concentration of $\mathrm{Fe}$ and $\mathrm{Mn}$ in the lower section, sudden increase in the middle section and maintaining higher values in the upper section in the core collected near mouth indicates early diagenetic process. The distribution pattern of $\mathrm{Fe}$ and $\mathrm{Mn}$ has been used to understand their post-depositional behavior by Singh and Nayak (2009) earlier. The sudden increase in redox sensitive elements namely in $\mathrm{Fe}$ and $\mathrm{Mn}$ above $30 \mathrm{~cm}$ depth indicates changing redox condition from anoxic to oxic, wherein there is migration of $\mathrm{Fe}^{2+}$ and $\mathrm{Mn}^{2+}$ species which are produced as a result of $\mathrm{Fe}-\mathrm{Mn}$ oxyhydroxide dissolution in the partly reduced sediment layer below $30 \mathrm{~cm}$ and reprecipitation near the oxic-suboxic interface (Sundararajan and Natesan 2010). Further, a similar point-to-point variation of $\mathrm{Fe}$ and $\mathrm{Mn}$ is observed between 56 and $52 \mathrm{~cm}$ in the lower section, 30-24 cm in the middle section and $14 \mathrm{~cm}$ to the surface in the upper section of the core. This is also supported by strong positive correlation between $\mathrm{Fe}$ and $\mathrm{Mn}$ (Table 3) indicating strong association of the geochemical matrix between the two elements (Jonathan et al. 2010). From the overall distribution pattern, sudden increase in concentration of $\mathrm{Fe}$ and $\mathrm{Mn}$ in the middle section of the core is the result of formation of insoluble oxyhydroxides in the oxic sediment layer (Fernandes and Nayak 2009) of muddy sand. This is also supported by the significant positive correlation of Mn with sand (Table 3).

A peak value of $\mathrm{Mn}$ at $12 \mathrm{~cm}$ along with slight increase in Fe concentration at this depth in the core collected from the inner portion of the creek probably indicates precipitation of $\mathrm{Fe}$ and $\mathrm{Mn}$-oxides in the oxic sediments (Caetano et al. 2009). However, $\mathrm{Fe}$ and $\mathrm{Mn}$ show negatively correlation (Table 4) between themselves and also, no significant correlation of $\mathrm{Fe}$ and $\mathrm{Mn}$ with sediment components indicating difference in processes of deposition. Differences in $\mathrm{Fe}$ and $\mathrm{Mn}$ distribution pattern and their associations, in the inner core could be due to difference in hydrodynamics, elemental behavior with respect to physico-chemical conditions and source of supply.

$\mathrm{Al}$ indicates terrigenous input and is the major component in the clay lattice. In the core collected towards the mouth of the creek, $\mathrm{Al}$ varies from 6.38 to $10.5 \%$ (average $8.66 \%$ ). A large fluctuating trend is seen (Fig. 4a) along the length of the core with relatively higher values towards the bottom and top of the core. In the lower section of the core $\mathrm{Al}$ shows an overall decreasing trend with peaks of high and low values in between. Distribution of $\mathrm{Al}$ agrees with that of organic carbon between 38 and $30 \mathrm{~cm}$. In the middle section of the core, an overall increasing trend is noted. In the upper section of the core, $\mathrm{Al}$ concentration is higher at $12 \mathrm{~cm}$ followed by a gradual decrease up to $4 \mathrm{~cm}$. In the core collected from the inner portion of the creek, $\mathrm{Al}$ varies from 7.78 to $10.3 \%$ with an average value of $8.96 \%$. $\mathrm{Al}$ is observed to have higher concentration in the middle and lower portion of the core (Fig. 5a). The variation in $\mathrm{Al}$ concentration in the upper and bottom part of the core agrees with the distribution pattern of clay. In the lower section of the core, $\mathrm{Al}$ shows an increasing trend similar to that of finer sediment components and organic carbon, except at $20 \mathrm{~cm}$ where $\mathrm{Al}$ concentration decreases. In the upper section of the core, $\mathrm{Al}$ increases up to $14 \mathrm{~cm}$ followed by a decrease up to the surface.

Correlation coefficient indicated no significant relationship of $\mathrm{Al}$ with any of the sediment components for the core collected towards the mouth of the creek (Table 3). In the core collected towards the inner portion of the creek, $\mathrm{Al}$ exhibited significant positive correlation with clay size fraction (Table 4) indicating its natural source. The association of $\mathrm{Al}$ with fine-grained sediments suggests that they are detrital minerals dominated by phyllosilicates (Buckley 
and Cranston 1991; Jonathan et al. 2004). No significant relationship of $\mathrm{Al}$ with $\mathrm{Fe}, \mathrm{Mn}$ and organic carbon indicates that they are derived from different sources.

\section{Trace metals}

In core collected towards the mouth of the creek, the concentration of metals varied from 183 to $493 \mathrm{ppm}$ (avg. $297 \mathrm{ppm}$ ) for $\mathrm{V}, 110-173 \mathrm{ppm}$ (avg. $128 \mathrm{ppm}$ ) for $\mathrm{Ni}$, 100-156 ppm (avg. $129 \mathrm{ppm}$ ) for $\mathrm{Cu}, 165-268$ (avg. $197 \mathrm{ppm}$ ) for Zn, 4.67-116 ppm (avg. $46.6 \mathrm{ppm}$ ) for $\mathrm{Pb}$. In general $\mathrm{V}, \mathrm{Cu}$ and to some extent $\mathrm{Zn}$ concentrations are lower in the lower section of the core as compared to the middle and upper sections (Fig. 4b). Ni concentration is high in the upper section as compared to the lower and the middle, while, $\mathrm{Pb}$ concentration is high towards the bottom and top of the core. The lower section of the core shows an overall decreasing trend of V. Similarly, $\mathrm{Cu}$ and $\mathrm{Pb}$ also show a decreasing trend with fluctuations and agree with $\mathrm{Fe}$ and $\mathrm{Mn}$. As compared to these, not much variation in $\mathrm{Zn}$ and $\mathrm{Ni}$ concentration is observed. In addition, $\mathrm{Zn}$ also shows similar point-to-point distribution pattern as that of $\mathrm{Al}$ in this section between 50 and $30 \mathrm{~cm}$. In the middle section of the core, $\mathrm{V}, \mathrm{Cu}$ and $\mathrm{Zn}$ show drastic increase agreeing with sand, $\mathrm{Fe}$ and $\mathrm{Mn}$ distribution. The increased concentration of metals in the coarser fractions may be attributed to inputs from the anthropogenic sources such as industrial wastes. A gradual increasing trend is noted for $\mathrm{Ni}$ with a slightly lower value at $22 \mathrm{~cm}$ depth. Decrease in concentration at this depth is also observed for $\mathrm{Cu}, \mathrm{Zn}$ and $\mathrm{V}$. $\mathrm{Pb}$ shows a fluctuating trend in this section. In the upper section of the core, $\mathrm{Ni}, \mathrm{Cu}$ and to some extent $\mathrm{V}$ increases up to $8 \mathrm{~cm}$ followed by a decrease towards the surface. $\mathrm{Zn}$ concentration is the highest at $12 \mathrm{~cm}$ and coincides with Mn peak at this depth. This is followed by a sudden decrease at $10 \mathrm{~cm}$ depth above which a gradual decrease up to the surface is observed for $\mathrm{Zn}$ and agrees well with $\mathrm{Al}$ except at the surface. $\mathrm{Pb}$ shows decrease up to $10 \mathrm{~cm}$ followed by an increase up to the surface. The higher concentration of metals in the middle and upper sections of the core, similar to that of $\mathrm{Fe}$ and $\mathrm{Mn}$, indicates precipitation of $\mathrm{Fe}-\mathrm{Mn}$ oxyhydroxides and co-precipitation of metals in the top sections of the core that were in contact with oxygenated bottom waters (Selvaraj et al. 2010). This is also supported by significant positive correlation of metals namely $\mathrm{V}, \mathrm{Cu}, \mathrm{Ni}$ and $\mathrm{Zn}$ with $\mathrm{Fe}$ and $\mathrm{Mn}$ (Table 3). No major influence of sediment components on the distribution of metals is evident except for $\mathrm{V}$ and $\mathrm{Mn}$ which shows significant positive correlation with sand and $\mathrm{Ni}$ with that of clay. Thus oxides of Fe and Mn can be considered as the most important component in influencing processes of metal transport and distribution (Thomas and Bendell-
Young 1999) in this core except for Pb which seems not influenced by diagenetic processes.

In the core collected from the inner portion of the creek, concentration of metals varied from 262 to $426 \mathrm{ppm}$ (avg. $341 \mathrm{ppm}$ ) for $\mathrm{V}, 128-506 \mathrm{ppm}$ (avg. $336 \mathrm{ppm}$ ) for $\mathrm{Ni}$, 155-1,555 ppm (avg. $795 \mathrm{ppm}$ ) for $\mathrm{Cu}, 346-8,101 \mathrm{ppm}$ (avg. 2,835 ppm) for Zn and 249-335 ppm (avg. $284 \mathrm{ppm}$ ) for $\mathrm{Pb}$. In general $\mathrm{V}, \mathrm{Ni}, \mathrm{Cu}$ and $\mathrm{Zn}$ show increasing trend and $\mathrm{Pb}$ shows an overall decreasing trend from bottom to the top of the core (Fig. 5b). In the lower section of the core, overall slightly decreasing trend of $\mathrm{V}$ is noted with its minimum concentration at $26 \mathrm{~cm}$, while $\mathrm{Ni}, \mathrm{Cu}$ and $\mathrm{Zn}$ show an increasing trend agreeing with the distribution pattern of finer sediment components and organic carbon. In the upper section of the core, $\mathrm{V}$ shows a fluctuating trend. $\mathrm{Ni}, \mathrm{Cu}$ and $\mathrm{Zn}$ show the same variation patterns as that of organic carbon at all depths between $20 \mathrm{~cm}$ up to the surface. $\mathrm{Pb}$ distribution matches that of $\mathrm{Fe}$ and show same point-to-point variation pattern from $20 \mathrm{~cm}$ up to surface of the core. No similarity of $\mathrm{Pb}$ with Mn distribution pattern was observed. The observed differences in association of $\mathrm{Pb}$ with $\mathrm{Fe}$ and $\mathrm{Mn}$ may be the result of the important role played by $\mathrm{Fe}$ oxide recycling in the precipitation of $\mathrm{Pb}$ as compared to $\mathrm{Mn}$, cycling of which is less important (Ruiz-Fernández et al. 2009).

Correlation values indicate significant positive association of $\mathrm{Pb}$ with sand. Although metals are usually associated with finer fractions they have also been shown to accumulate on the surface of coarser materials like sand (Kljakovic-Gašpic et al. 2009). V, Cu, Ni, Zn along with organic carbon show significant positive correlation with finer sediment fractions (Table 4). Finer-grained fractions and their associated sediment phases have a higher proportion of trace elements more often greater than the coarse-grained sediments which are connected with larger surface area of smaller particles (Mikulic et al. 2008). Also, the strong correlation between these elements and organic carbon underlines an association in the form of organometallic complexes (Zourarah et al. 2009). No significant correlation of metals with $\mathrm{Al}$ is evident. Weaker correlation of metals with $\mathrm{Al}$ which is a geochemical proxy suggest that factors other than particle size contribute significantly to the variations of these elements (Zhang et al. 2007). Fe and $\mathrm{Mn}$ are also observed to have no influence on the distribution of metals in this core indicating absence of diagenetic enrichment. Thus correlation analyses strongly support anthropogenic addition of metals to this part of the creek. Within the Tarapur MIDC area 1,182 industries are present and include chemical, pharmaceutical, engineering, steel, textile, glass, rubber, tiles, marble, packaging, paper, plastic, food, decorative plywood, wood and others. These industries use raw materials such as inorganic and organic compounds, dyes, pigments, bulk drugs, oils, alloy and non 
alloy steel sheets, ferrous and non-ferrous materials, metallic powder, aluminium alloys, scrap and annealed wire, stainless steel and steel wire rods, color and chemicals, asbestos, chemical solvents like zinc oxide, raw rubber, cement chips, plastic, sugar, etc. Amongst these, dye and dye intermediates, iron and steel, pesticides, drugs and pharmaceuticals are categorized as highly polluting industries at Tarapur (MPCB 2010). According to MPCB report (2005) the wastewater generated from the cities located in the Thane region along with industrial effluent is finally disposed off in the nearby creeks. Elevated concentrations and the increase of metals from the bottom to the top of the core in the present study indicate addition of metals from industrial effluents, the magnitude of which has increased in recent years.

Distribution of metals varies largely in the two cores. The core collected towards the mouth has lower average concentration of most of the metals as compared to the core collected from the inner portion of the creek. This may be because of the influence of tidal flushing which is higher towards the mouth as compared to the inner portion of the creek where tidal flushing is probably not effective in removal of finer sediments, organic matter and associated metals. Variations in parameters between locations can be well depicted using an "isocon" plot (Cundy et al. 1997). An isocon is a straight line through the origin. The slope of the isocon defines the mass change in the alteration, and the deviation of a data point from the isocon defines the concentration change for the corresponding component (Grant 1986). From the distribution of the average data points it is observed that sediment components, organic carbon, Fe, $\mathrm{Mn}, \mathrm{Al}$, and $\mathrm{V}$ lie close to the straight line (Fig. 6), thus indicating little or no variation in their composition and therefore are said to be of natural origin or less affected by anthropogenic processes in both the cores. The trace metals mainly $\mathrm{Zn}, \mathrm{Ni}, \mathrm{Cu}$ and $\mathrm{Pb}$, lie away from the line and lie towards the core collected from the inner portion of the creek, thus indicating elevated concentrations of metals originating from anthropogenic sources in the inner portion of the creek as compared to the sediments towards the mouth. It is also evident that anthropogenic addition of $\mathrm{Zn}$ is highest in comparison with other metals.

\section{Factor analysis}

In order to understand the source of metal input in sediments of Dudh creek, R-mode factor analysis has been performed. The factor loadings are presented in Table $5 \mathrm{a}, \mathrm{b}$ for both cores. For core collected towards the mouth, three factors could be extracted (Fig. 7a) contributing to about $81 \%$ of the total variance with Eigenvalue $>1$. From the figure, two groups can be identified for all the three factors and named as positively and negatively loaded. For the first

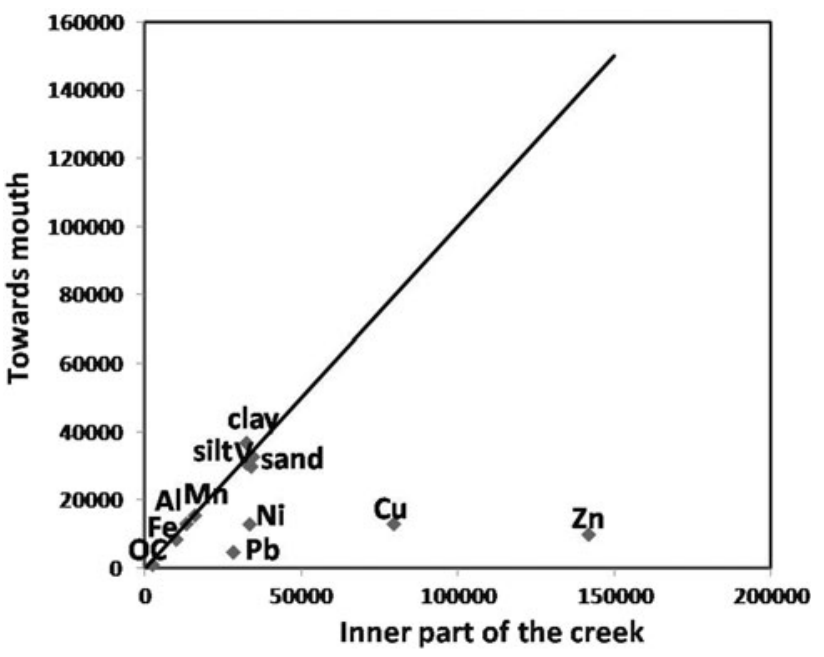

Fig. 6 Isocon plot. Each element has been multiplied by the same number in both the cores to ensure that it plots on the same scale. Also to separate the closely spaced average data points, sand, silt, clay, organic carbon, $\mathrm{Al}$ and $\mathrm{Fe}$ are multiplied by $1000, \mathrm{Ni}, \mathrm{Cu}, \mathrm{V}, \mathrm{Pb}$ by $100, \mathrm{Zn}$ and Mn by 50

factor, finer sediment components and organic carbon are observed to be positively loaded, thus indicating association of organic matter with fine-grained sediments. All the studied metals along with sand are negatively loaded out of which $\mathrm{Fe}, \mathrm{Mn}, \mathrm{V}$ and $\mathrm{Cu}$ loadings are significant. They are thus opposite in behavior to those of the first group and indicate adsorption of metals, especially $\mathrm{V}$ and $\mathrm{Cu}$ onto $\mathrm{Fe}-\mathrm{Mn}$ oxyhydroxide precipitate. In the second factor, significant positive loading of sand and negative loading of clay indicate differences in their geochemical behavior. Factor 3 is less significant as compared to factor 1 and 2 and does not represent any major associations. Thus it is clear that in the core collected towards the mouth, sediment components and organic carbon does not play a major role in metal distribution. Even $\mathrm{Fe}-\mathrm{Mn}$ oxyhydroxides are not effective enough in controlling the distribution of most of the metals, except for $\mathrm{V}$ and $\mathrm{Cu}$.

For core collected from the inner portion of the creek, two factors could be extracted (Fig. 7b) accounting for $78 \%$ of the total variance with Eigenvalue $>1$. In the first factor sand and $\mathrm{Pb}$ are significantly positively loaded. This group also includes $\mathrm{Mn}$ with lower loadings and minor loadings of $\mathrm{Fe}$ indicating little influence of $\mathrm{Fe}-\mathrm{Mn}$ oxyhydroxides on the distribution of $\mathrm{Pb}$. This also indicates that $\mathrm{Pb}$ is from different source when compared to other trace metals. Silt, organic carbon, $\mathrm{V}, \mathrm{Cu}, \mathrm{Ni}$ and $\mathrm{Zn}$ are significantly negatively loaded indicating association of metals with one of the finer sediment components, i.e. silt and organic carbon and has associations that are different from the first group. Factor 2 shows significant positive loadings of clay and $\mathrm{Al}$ of lithogenic origin and having no association with trace metals. Factor analysis thus supports 
different sources including anthropogenic input of metals to the creek, the main source of which can be industrial effluents from Tarapur MIDC area which are continuously

Table 5 Factor loadings for (a) mouth b)the inner part of the creek

\begin{tabular}{lccc}
\hline & Factor 1 & Factor 2 & Factor 3 \\
\hline (a) Core collected towards the mouth & & \\
Sand & -0.57 & $0.79^{\mathrm{a}}$ & 0.16 \\
$\mathrm{Silt}$ & $0.72^{\mathrm{a}}$ & -0.62 & -0.09 \\
$\mathrm{Clay}$ & 0.42 & $-0.87^{\mathrm{a}}$ & -0.21 \\
$\mathrm{OC}$ & $0.82^{\mathrm{a}}$ & -0.09 & 0.39 \\
$\mathrm{~V}$ & $-0.73^{\mathrm{a}}$ & -0.00 & 0.30 \\
$\mathrm{Cu}$ & $-0.87^{\mathrm{a}}$ & -0.38 & -0.07 \\
$\mathrm{Ni}$ & -0.51 & -0.66 & -0.37 \\
$\mathrm{~Pb}$ & -0.13 & -0.51 & 0.53 \\
$\mathrm{Zn}$ & -0.68 & -0.23 & 0.05 \\
$\mathrm{Mn}$ & $-0.88^{\mathrm{a}}$ & -0.07 & 0.00 \\
Fe & $-0.89^{\mathrm{a}}$ & -0.30 & -0.15 \\
$\mathrm{Al}$ & -0.20 & -0.56 & 0.65 \\
Expl.Var & 5.34 & 3.08 & 1.2 \\
Prp.Totl & 0.45 & 0.26 & 0.1 \\
\hline
\end{tabular}

Factor $1 \quad$ Factor 2

(b) Core collected from the inner part of the creek

$\begin{array}{lrr}\text { Sand } & 0.81^{\mathrm{a}} & -0.50 \\ \mathrm{Silt} & -0.89^{\mathrm{a}} & 0.11 \\ \mathrm{Clay} & -0.46 & 0.82^{\mathrm{a}} \\ \mathrm{OC} & -0.91^{\mathrm{a}} & -0.41 \\ \mathrm{~V} & -0.81^{\mathrm{a}} & -0.27 \\ \mathrm{Cu} & -0.92^{\mathrm{a}} & -0.15 \\ \mathrm{Ni} & -0.84^{\mathrm{a}} & 0.15 \\ \mathrm{~Pb} & 0.81^{\mathrm{a}} & -0.16 \\ \mathrm{Zn} & -0.81^{\mathrm{a}} & -0.49 \\ \mathrm{Mn} & 0.68 & 0.51 \\ \mathrm{Fe} & 0.07 & -0.63 \\ \mathrm{Al} & -0.36 & 0.81^{\mathrm{a}} \\ \text { Expl.Var } & 6.64 & 2.81 \\ \text { Prp.Totl } & 0.55 & 0.23\end{array}$

Extraction: Principal components $\left({ }^{\mathrm{a}}\right.$ Marked loadings are $\left.>0.7\right)$ being drained into the Dudh creek due to which the creek is almost perpetually full of leaked effluents (Naik et al. 2007). However, $\mathrm{Pb}$ may be from vehicular source.

Pollution level in Dudh creek

The average values of EF and $I_{\text {geo }}$ of the studied metals in both the cores revealed that the sediments of Dudh creek are severely enriched and extremely polluted with $\mathrm{Zn}, \mathrm{Cu}$, $\mathrm{Ni}, \mathrm{Pb}$ followed by $\mathrm{V}$. $\mathrm{Fe}$ and $\mathrm{Mn}$ also show minor enrichment (Table $6 a, b)$. Spatial variation in the degree of pollution is also clearly evident within the creek and is observed to be of major concern especially towards the inner portion where the level of trace metal enrichment is many folds higher than the core collected towards the mouth. Less concentration of metals near the mouth may be due to good tidal flushing especially during ebb tide, dragging most of the contaminants towards the sea before it can settle in the creek. Also, from the depth variation of EF (Fig. 8a, b) and $I_{\text {geo }}$ (Fig. 9a, b) an increase in magnitude of enrichment is seen for most of the metals from bottom to top of the core and thus has resulted in extreme deterioration of sediment quality of the creek in recent years, due to the release of waste from MIDC.

If an EF value is between 0.5 and 1.5 , it suggests that the trace metals may be entirely from crustal materials or natural weathering processes Zhang and Liu (2002) and if an $\mathrm{EF}$ is greater than 1.5, it suggests that a significant portion of trace metal is delivered from non-crustal or natural weathering processes, the trace metals are provided by other sources (Feng et al. 2004). Higher values obtained in the present case strongly support anthropogenic source.

\section{Conclusion}

The sudden and large increase in sand percentage in the middle and lower sections of core collected towards the mouth and core collected towards the inner portion of the creek, respectively, indicate deposition of sediment under high hydrodynamic energy conditions at these depths. The
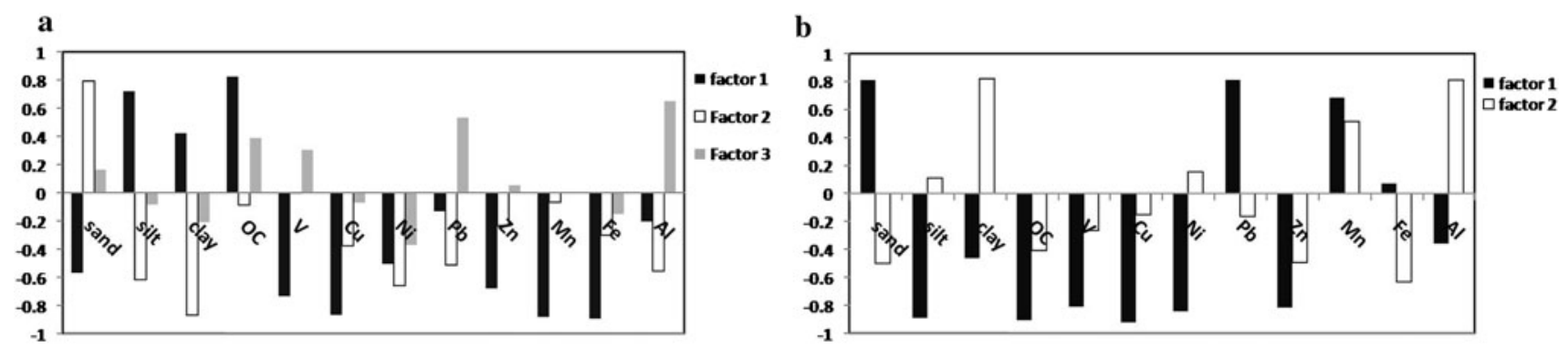

Fig. 7 R-mode factor analysis for a core collected towards the mouth $\mathbf{b}$ core collected from the inner portion of the creek 
Table 6 Average values of EF and $I_{\text {geo }}$ in core collected (a) towards the mouth (b) Average values of EF and $I_{\text {geo }}$ in core collected from the inner part of the creek

\begin{tabular}{lllll}
\hline Metal & Avg EF & Level & Avg $I_{\text {geo }}$ value & Sediment quality \\
\hline (a) Average values of EF and $I_{\text {geo }}$ in core collected towards the mouth & & Moderately to highly polluted \\
$\mathrm{V}$ & 5 & Moderate enrichment & 2.4 & Moderately to highly polluted \\
$\mathrm{Cu}$ & 8.2 & Moderately severe & 2.1 & Moderately polluted \\
$\mathrm{Ni}$ & 6.2 & Moderately severe & 1.5 & Moderately polluted \\
$\mathrm{Pb}$ & 2.4 & Minor enrichment & 1.5 & Moderately polluted \\
$\mathrm{Zn}$ & 3.4 & Moderate enrichment & 1.6 & Moderately polluted \\
$\mathrm{Mn}$ & 2.6 & Minor enrichment & Moderately polluted \\
$\mathrm{Fe}$ & 2.6 & Minor enrichment & 1.9 & \\
$(\mathrm{~b})$ Average values of $\mathrm{EF}$ and $I_{\text {geo }}$ in core collected from the inner part of the creek & 3.3 & Highly polluted \\
$\mathrm{V}$ & 5.6 & Moderately severe & 4.4 & Highly to very highly polluted \\
$\mathrm{Cu}$ & 47.8 & Very severe & 2.8 & Moderately to highly polluted \\
$\mathrm{Ni}$ & 15.6 & Severe & 4.4 & Highly to very highly polluted \\
$\mathrm{Pb}$ & 15 & Severe & 4.9 & Highly to very highly polluted \\
$\mathrm{Zn}$ & 48 & Very severe & 1.9 & Moderately polluted \\
$\mathrm{Mn}$ & 2.7 & Minor enrichment & 1.7 & Moderately polluted \\
$\mathrm{Fe}$ & 2.9 & Minor enrichment &
\end{tabular}
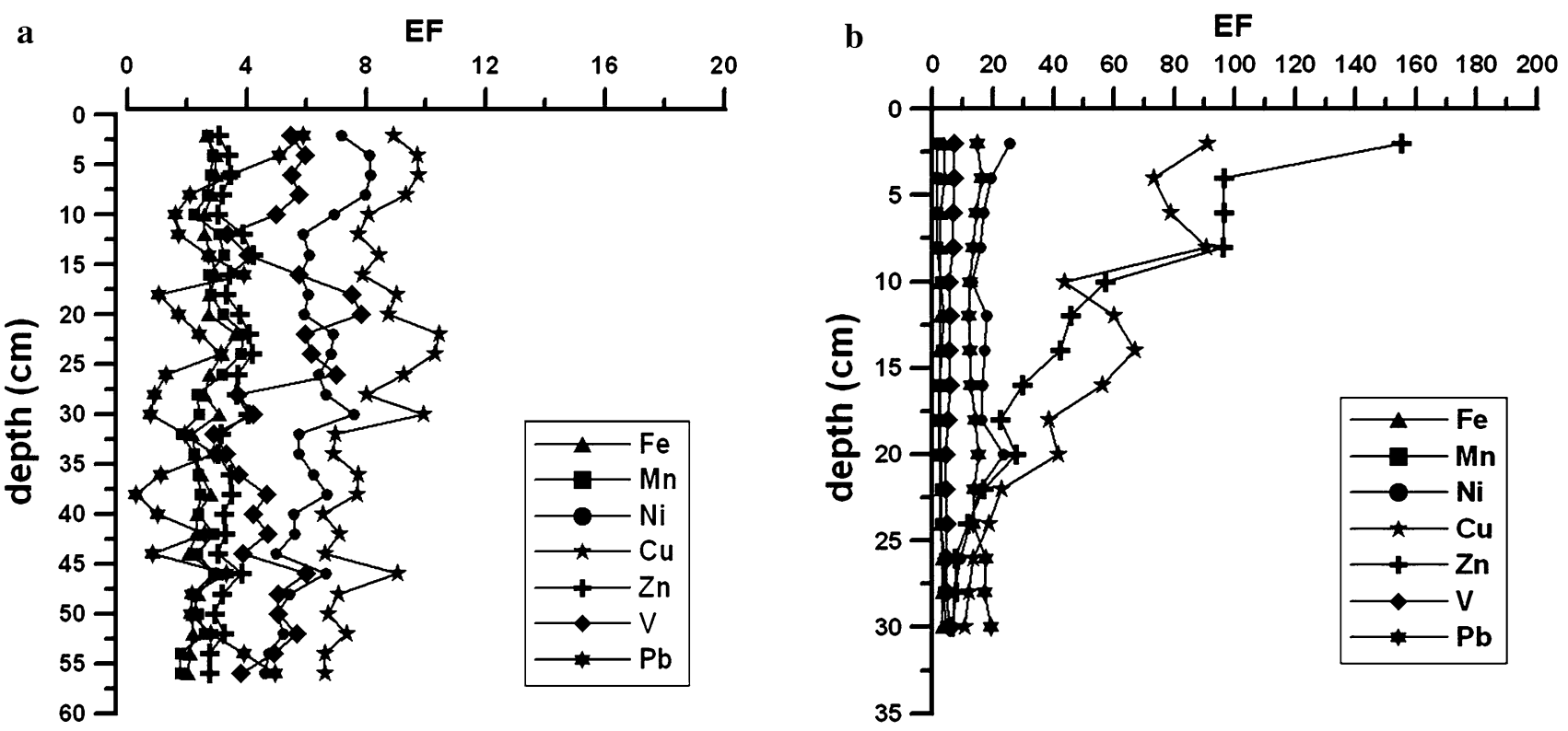

Fig. 8 Depth distribution of enrichment factor for a core collected towards the mouth $\mathbf{b}$ core collected from the inner portion of the creek

increased concentration of $\mathrm{Fe}$ and $\mathrm{Mn}$ along with other metals in the middle and upper sections of the core collected towards the mouth pointed towards anthropogenic addition in recent years. Correlation analyses helped in understanding strong association between elements $(\mathrm{V}, \mathrm{Cu}, \mathrm{Ni}$, and $\mathrm{Zn})$, silt and organic carbon which is probably in the form of organometallic complexes in the core collected from the inner portion of the creek. Sediment components and organic carbon were found to have negligible or minor influence on metal distribution in core collected towards the mouth.
The observed elevated concentrations of metals and organic carbon towards the inner portion of the creek has been attributed to less effective tidal flushing as compared to the mouth. Isocon plot has helped to depict variations in parameters between sites. From the distribution of average data points, sediment components, organic carbon, $\mathrm{Fe}, \mathrm{Mn}$, $\mathrm{Al}$ and $\mathrm{V}$ were found to be of natural origin or are less affected by anthropogenic processes in both the cores, while $\mathrm{Zn}, \mathrm{Ni}, \mathrm{Cu}$ and $\mathrm{Pb}$ had elevated concentrations originating from anthropogenic sources towards the inner 

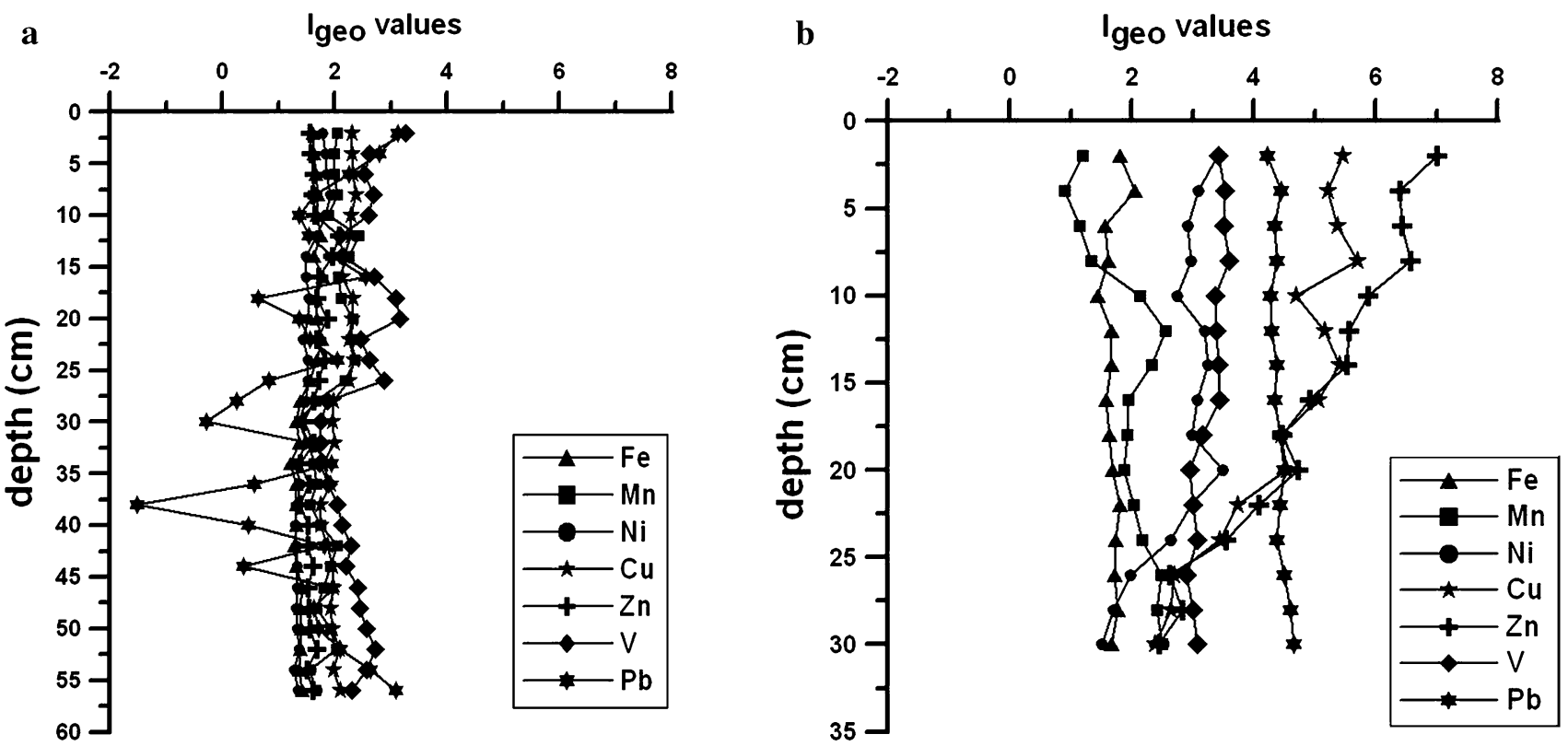

Fig. 9 Depth distribution of values of index of geoaccumulation $\left(I_{\text {geo }}\right)$ for a core collected towards the mouth $\mathbf{b}$ core collected from the inner portion

portion of the creek as compared to the mouth. Factor analysis also pointed towards anthropogenic input of metals to the creek as the main source from the nearby industries. EF and $I_{\text {geo }}$ helped to study the level of pollution in the sediments of Dudh creek. The creek is found to be severely enriched with $\mathrm{Zn}, \mathrm{Cu}, \mathrm{Ni}, \mathrm{Pb}$ followed by $\mathrm{V}$, while $\mathrm{Fe}$ and $\mathrm{Mn}$ showed minor enrichment. The sediment quality of Dudh creek has deteriorated especially in recent years by the addition of waste from Tarapur MIDC.

Acknowledgments One of the authors (S.P. Volvoikar) wish to thank the University Grants Commission (UGC) for granting fellowship under the "Research Fellowships in Sciences for Meritorious Students" scheme. Our sincere thanks go to Dr. Rajeev Saraswat, Scientist, National Institute of Oceanography (NIO), Goa, for his valuable and important comments on the manuscript.

\section{References}

Achyuthan H, Richardmohan D, Srinivasalu S, Selvaraj K (2002) Trace metals concentrations in the sediment cores of estuary and tidal zones between Chennai and Pondicherry, along the east coast of India. Indian J Mar Sci 31(2):141-149

Ayyamperumal T, Jonathan MP, Srinivasalu S, Armstrong-Altrin JS, Ram-Mohan V (2006) Assessment of acid leachable trace metals in sediment cores from River Uppanar, Cuddalore, Southeast coast of India. Environ Pollut 143:34-45

Badr NBE, El-Fiky AA, Mostafa AR, Al-Mur BA (2009) Metal pollution records in core sediments of some Red Sea coastal areas, Kingdom of Saudi Arabia. Environ Monit Assess 155:509-526. doi:10.1007/s10661-008-0452-x

Bhagure GR, Mirgane SR (2010) Heavy metal concentrations in groundwaters and soils of Thane region of Maharashtra, India. Environ Monit Assess. doi:10.1007/s10661-010-1412-9
Buckley DE, Cranston RE (1991) The use of grain size information in marine geochemistry. In: Syvitski JM (ed) Principles, methods and applications of particle size analysis. Cambridge University Press, New York, pp 311-331

Caetano M, Prego R, Vale C, de Pablo H, Marmolejo-Rodríguez J (2009) Record of diagenesis of rare earth elements and other metals in a transitional sedimentary environment. Mar Chem 116:36-46

Chen C-W, Kao C-M, Chen C-F, C-Di Dong (2007) Distribution and accumulation of heavy metals in the sediments of Kaohsiung Harbour, Taiwan. Chemosphere 66:1431-1440

Cundy AB, Croudace IW, Thomson J, Lewis JT (1997) Reliability of salt marshes as "Geochemical Recorders" of pollution input: a case study from contrasting estuaries in Southern England. Environ Sci Technol 31:1093-1101

Dai J, Song J, Li X, Yuan H, Li N, Zheng G (2007) Environmental changes reflected by sedimentary geochemistry in recent hundred years of Jiaozhou Bay, North China. Environ Pollut 145:656-667

Dolch T, Hass HC (2008) Long-term changes of intertidal and subtidal sediment compositions in a tidal basin in the northern Wadden Sea (SE North Sea). Helgol Mar Res 62:3-11. doi: 10.1007/s10152-007-0090-7

Feng H, Han X, Zhang W, Yu L (2004) A preliminary study of heavy metal contamination in Yangtze River intertidal zone due to urbanization. Mar Pollut Bull 49:910-915

Fernandes L, Nayak GN (2009) Distribution of sediment parameters and depositional environment of mudflats of Mandovi estuary, Goa, India. J Coastal Res 25(2):273-284

Fernandes L, Nayak GN, Ilangovan D, Borole DV (2011) Accumulation of sediment, organic matter and trace metals with space and time, in a creek along Mumbai coast, India. Estuar Coast Shelf Sci 91:388-399

Fianko JR, Osae S, Adomako D, Adotey DK, Serfor-Armah Y (2007) Assessment of heavy metal pollution of the Iture estuary in the central region of Ghana. Environ Monit Assess 131:467-473. doi:10.1007/s10661-006-9492-2

Folk RL (1968) Petrology of sedimentary rocks. Hemphills, Austin, p 177 
Fox WM, Johnson MS, Jones SR, Leah RT, Copplestone D (1999) The use of sediment cores from stable and developing salt marshes to reconstruct historical contamination profiles in the Mersey Estuary, UK. Mar Environ Res 47:311-329

Gaudette HE, Flight WR, Toner L, Folger DW (1974) An inexpensive titration method for the determination of organic carbon in recent sediments. J Sediment Petrol 44:249-253

Grant JA (1986) The ISOCON diagram-a simple solution to Gresen's equation for metasomatic alteration. Econ Geol 81:1976-1982

He ZL, Zhang M, Stoffella PJ, Yang XE (2006) Vertical distribution and water solubility of phosphorus and heavy metals in sediments of the St. Lucie Estuary, South Florida, USA. Environ Geol 50:250-260. doi:10.1007/s00254-006-0205-5

Hwang H-M, Green PG, Young TM (2009) Historical trends of trace metals in a sediment core from a contaminated tidal salt marsh in San Francisco Bay. Environ Geochem Health 31:421-430. doi: 10.1007/s10653-008-9195-4

Ip CCM, Li XD, Zhang G, Wai OWH, Li YS (2007) Trace metal distribution in sediments of the Pearl river estuary and the surrounding coastal area, South China. Environ Pollut 147:311-323

Janaki-Raman D, Jonathan MP, Srinivasalu S, Armstrong-Altrin JS, Mohan SP, Ram-Mohan V (2007) Trace metal enrichments in core sediments in Muthupet mangroves, SE coast of India: application of acid leachable technique. Environ Pollut 145(1):245-257

Jonathan MP, Ram-Mohan V, Srinivasalu S (2004) Geochemical variations of major and trace elements in recent sediments, off the Gulf of Mannar, the southeast coast of India. Environ Geol 45:466-480. doi:10.1007/s00254-003-0898-7

Jonathan MP, Sarkar SK, Roy PD, Alam Md A, Chatterjee M, Bhattacharya BD, Bhattacharya A, Satpathy KK (2010) Acid leachable trace metals in sediment cores from Sunderban mangrove wetland, India: an approach towards regular monitoring. Ecotoxicology 19:405-418. doi:10.1007/s10646-009-0426-y

Keil RG, Montluçon DB, Prahl FG, Hedges JI (1994) Sorptive preservation of labile organic matter in marine sediments. Nature 370:549-552

Kljaković-Gašpić Z, Bogner D, Ujević I (2009) Trace metals (Cd, Pb, $\mathrm{Cu}, \mathrm{Zn}$ and $\mathrm{Ni}$ ) in sediment of the submarine pit Dragon ear (Soline Bay, Rogoznica, Croatia). Environ Geol 58:751-760. doi:10.1007/s00254-008-1549-9

Kumar SP, Edward JKP (2009) Assessment of metal concentration in the sediment cores of Manakudy estuary, south west coast of India. Indian J Mar Sci 38(2):235-248

Kwokal Ž, Sarkar SK, Chatterjee M, Franciskovis-Bilinski S, Bilinski $\mathrm{H}$, Bhattacharya A, Bhattacharya BD, Alam A Md (2008) An assessment of mercury loading in core sediments of Sunderban Mangrove Wetland, India (a preliminary report). Bull Environ Contam Toxicol 81:105-112. doi:10.1007/s00128008-9443-4

Liaghati T, Preda M, Cox M (2003) Heavy metal distribution and controlling factors within the coastal plain sediments, Bells creek catchment, southeast Queensland, Australia. Environ Int 29:935-948

Mikulic N, Orescanin V, Elez L, Pavicic L, Pezelj D, Lovrencic I, Lulic S (2008) Distribution of trace elements in the coastal sea sediments of Maslinica Bay, Croatia. Environ Geol 53:1413-1419. doi:10.1007/s00254-007-0750-6

MPCB (2005) Maharashtra industrial development corporation report-environmental status of Thane region

MPCB (2010) Maharashtra industrial development corporationaction plan for Tarapur industrial area

Müller G (1969) Index of geoaccumulation in the sediments of the Rhine River. GeoJournal 2:108-118
Naik PK, Dehury BN, Tiwari AN (2007) Groundwater pollution around an industrial area in the coastal stretch of Maharashtra state, India. Environ Monit Assess 132:207-233

Pejrup M (1988) The triangular diagram for classification of estuarine sediments: a new approach. In: de Boer PL, Van Gelder A, Nios SD (eds) Tide influenced sedimentary environments and facies, D. Reidel, Dordrecht, pp 289-300

Priju CP, Narayana AC (2006) Spatial and temporal variability of trace element concentrations in a Tropical Lagoon, Southwest Coast of India: environmental Implications. J Coast Res SI39:1053-1057

Ramesh R, Purvaja R, Ramesh S, James RA (2002) Historical pollution trends in coastal environments of India. Environ Monit Assess 79:151-176

Ridgway J, Shimmield G (2002) Estuaries as repositories of historical contamination and their impact on shelf seas. Estuar Coast Shelf Sci 55:903-928. doi:10.1006/ecss.2002.1035

Ruiz F, Borrego J, González-Regalado ML, López- González N, Carro B, Abad M (2009) Interaction between sedimentary processes, historical pollution and microfauna in the Tinto Estuary (SW Spain). Environ Geol 58:779-783. doi:10.1007/s 00254-008-1551-2

Ruiz-Fernández AC, Frignani M, Hillaire-Marcel C, Ghaleb B, Arvizu MD, Raygoza-Viera JR, Páez-Osuna F (2009) Trace metals $(\mathrm{Cd}, \mathrm{Cu}, \mathrm{Hg}$ and $\mathrm{Pb})$ accumulation recorded in the intertidal mudflat sediments of three coastal lagoons in the Gulf of California, Mexico. Estuaries Coast 32:551-564. doi: 10.1007/s12237-009-9150-3

Selvaraj K, Parthiban G, Chen CTA, Lou JY (2010) Anthropogenic effects on sediment quality offshore southwestern Taiwan: assessing the sediment core geochemical record. Cont Shelf Res 30:1200-1210

Simex SA, Helz GR (1981) Regional geochemistry of trace elements in Checapeake Bay. Environ Geol 3:315-323

Singh KT, Nayak GN (2009) Sedimentary and geochemical signatures of depositional environment of sediments in mudflats from a microtidal Kalinadi Estuary, Central West coast of India. J Coast Res 25(3):641-650

Siraswar R, Nayak GN (2011) Mudflats in lower middle estuary as a favorable location for concentration of metals, west coast of India. Indian J Geo-Mar Sci 40(3):372-385

Sondi I, Juračić M, Pravdić V (1995) Sedimentation in a disequilibrium river-dominated estuary: the Raša River estuary (Adriatic Sea, Croatia). Sedimentology 42:769-782

Sondi I, Lojen S, Juračić M, Prohić E (2008) Mechanisms of land-sea interactions - the distribution of metals and sedimentary organic matter in sediments of a river-dominated Mediterranean karstic estuary. Estuar, Coast Shelf Sci 80:12-20

StatSoft (1999) Statistica computer program, version 5.5. StatSoft, Tulsa, OK

Stecko JRP, Bendell-Young L (2000) Contrasting the geochemistry of suspended particulate matter and deposited sediments within an estuary. Appl Geochem 15:753-775

Sundararajan M, Natesan U (2010) Geochemistry of core sediments from Mullipallam creek, South East coast of India. Environ Earth Sci 61:947-961. doi:10.1007/s12665-009-0414-9

Swamy GN, Sarma RV, Suryanarayana A (1982) Physical characteristics of the coastal waters between Navapur and Umbharat West coast of India Part I: Current pattern. Mahasagar-Bull Natl Inst Oceanogr 15(2):67-83

Thomas CA, Bendell-Young LI (1999) The significance of diagenesis versus riverine input in contributing to the sediment geochemical matrix of iron and manganese in an intertidal region. Estuar Coast Shelf Sci 48:635-647

Vaalgamma S, Conley DJ (2008) Detecting environmental change in estuaries: nutrient and heavy metal distributions in sediment 
cores in estuaries from the Gulf of Finland, Baltic Sea. Estuar Coast Shelf Sci 76:45-56

Valette-Silver NJ (1993) The use of sediment cores to reconstruct historical trends in contamination of estuarine and coastal sediments. Estuaries 16(3B):577-588

Wang S, Cao Z, Lan D, Zheng Z, Li G (2008) Concentration distribution and assessment of several heavy metals in sediments of west-four Pearl River Estuary. Environ Geol 55:963-975. doi: 10.1007/s00254-007-1046-6

Wedepohl KH (1995) The composition of the continental crust. Geochim Cosmochim Acta 59(7):1217-1232

Williams TP, Bubb JM, Lester JN (1994) Metal accumulation within salt marsh environments: a review. Mar Pollut Bull 28(5):277-290
Zhang J, Liu CL (2002) Riverine composition and estuarine geochemistry of particulate metals in China-Weathering features, anthropogenic impact and chemical fluxes. Estuar Coast Shelf Sci 54:1051-1070

Zhang W, Yu L, Lu M, Hutchinson SM, Feng H (2007) Magnetic approach to normalizing heavy metal concentrations for particle size effects in intertidal sediments in the Yangtze Estuary, China. Environ Pollut 147:238-244

Zourarah B, Maanan M, Robin M, Carruesco C (2009) Sedimentary records of anthropogenic contribution to heavy metal content in Oum Er Bia estuary (Morocco). Environ Chem Lett 7:67-78. doi:10.1007/s10311-008-0138-1 